\title{
Inheritance and Molecular Mapping of Barley Genes Conferring Resistance to Wheat Stripe Rust
}

\author{
Vihanga Pahalawatta and Xianming Chen
}

First author: Washington State University, Department of Plant Pathology, Pullman 99164; and second author: U.S. Department of Agriculture-Agricultural Research Service, Wheat Genetics, Quality, Physiology, and Disease Research Unit and Washington State University, PNNS 0390, College of Agriculture Research Center, Pullman 99164.

Accepted for publication 31 March 2005.

\begin{abstract}
Pahalawatta, V., and Chen, X. M. 2005. Inheritance and molecular mapping of barley genes conferring resistance to wheat stripe rust. Phytopathology 95:884-889.

Most barley cultivars are resistant to stripe rust of wheat that is caused by Puccinia striiformis f. sp. tritici. The barley cv. Steptoe is susceptible to all identified races of $P$. striiformis $\mathrm{f}$. sp. hordei (PSH), the barley stripe rust pathogen, but is resistant to most $P$. striiformis f. sp. tritici races. To determine inheritance of the Steptoe resistance to P. striiformis f. sp. tritici, a cross was made between Steptoe and Russell, a barley cultivar susceptible to some $P$. striiformis $\mathrm{f}$. sp. tritici races and all tested P. striiformis f. sp. hordei races. Seedlings of parents and $\mathrm{F}_{1}, \mathrm{BC}_{1}, \mathrm{~F}_{2}$, and $\mathrm{F}_{3}$ progeny from the barley cross were tested with $P$. striiformis $\mathrm{f}$. $\mathrm{sp}$.

RpstS1 and rpstS2, respectively) for resistance to races PST-41 and PST45. Genomic DNA was extracted from the parents and $150 \mathrm{~F}_{2}$ plants that were tested for rust reaction and grown for seed of $\mathrm{F}_{3}$ lines. The infection type data and polymorphic markers identified using the resistance gene analog polymorphism (RGAP) technique were analyzed with the Mapmaker computer program to map the resistance genes. The dominant resistance gene in Steptoe for resistance to $P$. striiformis f. sp. tritici races was mapped on barley chromosome $4 \mathrm{H}$ using a linked microsatellite marker, HVM68. A linkage group for the dominant gene was constructed with 12 RGAP markers and the microsatellite marker. The results show that resistance in barley to the wheat stripe rust pathogen is qualitatively inherited. These genes might provide useful resistance against wheat stripe rust when introgressed into wheat from barley.
\end{abstract} tritici races PST-41 and PST-45 under controlled greenhouse conditions. Genetic analyses of infection type data showed that Steptoe had one dominant gene and one recessive gene (provisionally designated as
Additional keywords: Hordeum vulgare, nonhost resistance.
Stripe rust, caused by the fungal pathogen Puccinia striiformis Westend., occurs on wheat, barley, rye, and more than 18 genera of grasses (30). It is an economically important disease of wheat (Triticum aestivum L.) and barley (Hordeum vulgare L. emend. Bowden) in most regions of the world (35). In the United States, stripe rust of wheat was first recognized in 1915 (21) and has caused widespread damages since 1960 (8-10). The wheat stripe rust pathogen occasionally could occur on barley plants, but it never occurred at destructive intensities in fields of barley (6). The first reported incident of severe barley stripe rust in the United States occurred in 1991 (32). Barley stripe rust is now firmly established and destructive in western and south-central states and has been identified as an unique forma specialis $(3,6)$, whereas wheat stripe rust has been more widely distributed in the United States (9).

$P$. striiformis (referred to as $P$. glumarum) first was differentiated into formae speciales based on their distinct host range by Eriksson (12). Stripe rust of wheat is caused by P. striiformis f. sp. tritici and stripe rust of barley by $P$. striiformis f. sp. hordei. Newton et al. (26) demonstrated that $P$. striiformis f. sp. tritici and $P$. striiformis f. sp. hordei differed in isozyme mobility for two enzymes on starch gels and in the banding pattern of doublestranded RNA (dsRNA) molecules on polyacrylamide gels, whereas isolates within a forma specialis were uniform in their isozyme mobility. Using random amplified polymorphic DNA, Chen et al. (6) demonstrated that the two formae speciales are

Corresponding author: X. M. Chen; E-mail address: xianming@mail.wsu.edu

DOI: 10.1094/PHYTO-95-0884

This article is in the public domain and not copyrightable. It may be freely reprinted with customary crediting of the source. The American Phytopathological Society, 2005. clearly different but more closely related to each other than to $P$. striiformis f. sp. poae, which causes stripe rust on bluegrass. Although stripe rust had been found on barley plants in North America before P. striiformis f. sp. hordei spread to the region, the rust samples were identified as $P$. striiformis f. sp. tritici and never caused significant damage $(6,21)$. Studies on virulence of the two formae speciales infecting wheat and barley revealed that they have overlapping host ranges. However, the damage caused by $P$. striiformis f. sp. tritici on barley was negligible (6).

Most plant species are resistant to the majority of pathogens present in the environment. This type of resistance, initially considered to be pathogen nonspecific, is referred to as nonhost resistance. In contrast, resistance in plant genotypes within a plant species that is commonly susceptible to a pathogen is considered to be due to a gene-for-gene interaction in which pathogen factors that are products from avirulence (A) genes are recognized by the race-specific receptors that are products of resistance $(\mathrm{R})$ genes (13). In our genetic study of wheat resistance to the forma specialis $P$. striiformis f. sp. hordei, we identified a single dominant gene in Lemhi wheat for resistance to the barley stripe rust pathogen and mapped the gene to wheat chromosome 1B with resistance gene analog polymorphic (RGAP) markers (29). The objectives of this study were to determine inheritance of barley resistance to $P$. striiformis f. sp. tritici, and to map barley genes conferring resistance to the wheat stripe rust pathogen using the RGAP technique and chromosome-specific microsatellite markers.

\section{MATERIALS AND METHODS}

Plant materials. Crosses were made in the greenhouse between spring barley cvs. Steptoe (CIho 15229) and Russell (PI 
483127). Steptoe and Russell are susceptible to all races of P. striiformis f. sp. hordei identified so far in the United States, but Steptoe is resistant to most races and Russell is resistant to some races of $P$. striiformis $\mathrm{f}$. sp. tritici (6). Three crosses were made using different individual plants of each parent. Three to five $F_{1}$ seed from different crossed heads were planted in the greenhouse for making backcrosses and for selfing to produce $F_{2}$ seed. $F_{1}$ seed from each cross and $F_{2}$ seed from each $F_{1}$ plant were kept separately. Backcrosses were made from each parent using the $F_{1}$ plants as the female parent. $F_{2}$ seed were planted in the greenhouse for extracting DNA, testing for reaction to stripe rust, and producing seed of $\mathrm{F}_{3}$ lines. Leaves of each parent and 150 individual $\mathrm{F}_{2}$ plants were cut for DNA extraction and the plants were allowed to grow. $F_{3}$ seed harvested from the 150 individual $F_{2}$ plants were used for stripe rust tests.

Pathogen materials. Single-pustule isolates were obtained for races PST-41 and PST-45 of $P$. striiformis f. sp. tritici. Uredioniospores of the isolates were tested on the set of 20 wheat differential cultivars (9) to confirm the avirulent or virulent patterns of isolates. Among the 20 wheat genotypes that are used to differentiate races of $P$. striiformis $\mathrm{f}$. sp. tritici, race PST-41 is virulent on four (Lemhi, Heines VII, Moro, and Tres) and PST-45 on five (Lemhi, Heines VII, Fielder, Tyee, and Hyak) of the genotypes $(4,6)$. These two races were selected based on their virulence on Russell and avirulence on Steptoe. Pure uredioniospore isolates were increased on susceptible differential cultivars and used to evaluate for stripe rust resistance of the parents and progeny of the Steptoe $\times$ Russell cross.

Evaluation for stripe rust reaction. Standard methods for stripe rust testing in our lab as described by Chen and Line (2) were used in this study. Stripe rust reaction was evaluated on the $150 \mathrm{~F}_{2}$ plants, from which DNA was extracted, by inoculating plants at the jointing stage with urediniospores of race PST-45. Seedling tests also were performed for parents, $\mathrm{F}_{1}, \mathrm{BC}_{1}$, and $\mathrm{F}_{3}$ progeny using races PST-41 and PST-45. In all, 6 to 10 seedlings of each parent, 3 to $5 \mathrm{~F}_{1}$ seedlings, 35 to $45 \mathrm{BC}_{1}$ seedlings, and 15 to 20 of each of the $150 \mathrm{~F}_{3}$ lines were used for evaluating stripe rust resistance. All seedlings were grown in a rust-free greenhouse at a diurnal temperature cycle of 10 to $25^{\circ} \mathrm{C}$. Metal halide lights were used before and after inoculation to maintain a 16 -h photoperiod. Seedlings were uniformly inoculated with urediniospores of a test race mixed with talc (Sigma-Aldrich, St. Louis) at the two-leaf stage. Inoculated plants were placed in a dew chamber at $10^{\circ} \mathrm{C}$ for $24 \mathrm{~h}$. Seedlings then were moved to a growth chamber at temperatures programmed to change gradually between a minimum of 2 to $5^{\circ} \mathrm{C}$ at 2:00 a.m. during the 8-h dark period and a maximum of 18 to $20^{\circ} \mathrm{C}$ at 2:00 p.m. during the 16-h light period (2). Infection type (IT) data were recorded based on the 0-to-9 scale 18 to 21 days after inoculation (22). Infection types 0 to 3,4 to 6 , and 7 to 9 were considered to be resistant, intermediate, and susceptible reactions, respectively.

DNA extraction and analysis. Fresh leaves ( $3 \mathrm{~g})$ from individual $\mathrm{F}_{2}$ plants and parental genotypes were ground in liquid nitrogen. DNA was extracted from the leaf powder following the protocol described by Riede and Anderson (31). The extracted DNA was dissolved in $1 \times$ Tris-EDTA buffer $(10 \mathrm{mM}$ Tris- $\mathrm{HCl}$ and $1 \mathrm{mM}$ EDTA, $\mathrm{pH} 8.0$ ), and stored at $-20^{\circ} \mathrm{C}$. DNA was quantified using the mini-gel method (24) and spectrophotometer (Smartspec 3000; Bio-Rad, Hercules, CA) and concentration was adjusted to $30 \mathrm{ng} / \mu \mathrm{l}$. The previously described RGAP protocol $(7,34)$ was used in this study. Modifications to the reaction volume and ingredient amounts described by Yan et al. (39) were applied. Primers were designed based on conserved motifs of cloned resistance genes and synthesized by Operon (Alameda, CA). Polymerase chain reaction (PCR) amplification was performed in a DNA thermocycler (Perkin-Elmer, San Diego, CA) programmed for $5 \mathrm{~min}$ at $94^{\circ} \mathrm{C}$ for initial denaturation and 45 cycles each consisting of $1 \mathrm{~min}$ at $94^{\circ} \mathrm{C}, 1 \mathrm{~min}$ at $45^{\circ} \mathrm{C}$, and $2 \mathrm{~min}$ at $72^{\circ} \mathrm{C}$, fol- lowed by a final extension for $7 \mathrm{~min}$ at $72^{\circ} \mathrm{C}$. A 2.5 -min ramp time was used between the $94^{\circ} \mathrm{C}$ denaturation and the $45^{\circ} \mathrm{C}$ annealing steps. The fastest possible ramp was employed for all other temperature transitions.

The success of the amplification was checked by electrophoresing the PCR product in a $1 \%$ agarose gel. Formamide loading buffer $(6 \mu \mathrm{l} ; 98 \%$ formamide, $10 \mathrm{mM}$ EDTA [pH 8.0], $0.5 \%$ [wt/vol] bromophenol blue, and $0.5 \%$ [wt/vol] xylene cyanol) was added to the PCR product and mixed prior to loading $(4 \mu \mathrm{l})$ the agarose gel.

Successfully amplified DNA fragments were separated in a 5\% denaturing polyacrylamide gel ( 398 by 338 by $0.4 \mathrm{~mm}$ ), prepared according to manufacturer specifications. Gel was allowed to polymerize for $2 \mathrm{~h}$ and was pre-run in $1 \times$ Tris-borate-EDTA buffer (90 mM Tris-borate, $2 \mathrm{mM}$ EDTA [pH 8.0]) for 30 to $40 \mathrm{~min}$ at $1,600 \mathrm{~V}$, until the gel temperature reached $\approx 50^{\circ} \mathrm{C}$. PCR samples were denatured at $94^{\circ} \mathrm{C}$ for $3 \mathrm{~min}$ and 6 to $8 \mu \mathrm{l}$ of the sample was loaded into the wells. The loaded gel was run at $1,350 \mathrm{~V}$ for 3 to $3.5 \mathrm{~h}$, depending on the approximate size of the bands of interest. The gel was silver-stained according to the manufacturer's recommendation (Promega Corp., Madison, WI) and allowed to dry overnight at room temperature. Silver-sequence automatic processor compatible film (Promega Corp.) was used to produce a photograph of the gel.

Genomic DNA samples from Steptoe, Russell, and two DNA bulks of $\mathrm{F}_{2}$ progeny were used for screening primers. The two DNA bulks consisted of equal amounts of DNA from 10 homozygous resistant and 10 homozygous susceptible $F_{2}$ plants that were confirmed by testing the $\mathrm{F}_{3}$ progeny. Polymorphic RGAP bands specific to Steptoe and the resistant bulk were tested further in the $\mathrm{F}_{2}$ population consisting of 150 progeny. The segregation data of RGAP markers consisting of bands that matched the phenotypic disease data and the disease data obtained from the $F_{2}$ population were used to estimate the genetic linkage between the RGAP markers and the potential resistance gene.

To associate the linkage group of the resistance locus with a barley chromosome, 14 microsatellite markers, 2 for each of the seven chromosomes (23), were tested with genomic DNA samples from Steptoe, Russell, and the $\mathrm{F}_{2}$ progeny. The PCR reaction mixture was the same as for the RGAP markers described by Yan et al. (39) in a 15- $\mu$ l volume, except that the reaction mixture contained $1 \mu \mathrm{l}$ of plant DNA at $30 \mathrm{ng} / \mu \mathrm{l}$ and $1.5 \mu \mathrm{l}$ of $25 \mathrm{mM} \mathrm{MgCl}_{2}$ PCR amplification was performed in a DNA thermocycler (Perkin Elmer, San Diego, CA) using the following PCR conditions. The $\mathrm{PCR}$ reaction consisted of 18 cycles of $94^{\circ} \mathrm{C}$ for $1 \mathrm{~min}$ of denaturing and $72^{\circ} \mathrm{C}$ for a 1 -min extension. Annealing (30 s) temperatures gradually were decreased by $1^{\circ} \mathrm{C}$ every second cycle from 64 to $55^{\circ} \mathrm{C}$. The PCR reaction also consisted of 30 additional cycles of $94^{\circ} \mathrm{C}$ for $1 \mathrm{~min}, 55^{\circ} \mathrm{C}$ for $1 \mathrm{~min}$, and $72^{\circ} \mathrm{C}$ for $1 \mathrm{~min}$ followed by a final extension at $72^{\circ} \mathrm{C}$ for $5 \mathrm{~min}$.

Data analyses. To determine the goodness of fit of the observed compared with theoretical segregation ratios of the $\mathrm{F}_{2}$ and $\mathrm{F}_{3}$ progeny, $\chi^{2}$ tests were used to determine the number of stripe rust resistance genes, inheritance of resistance, and relationships of genes for resistance to the two different races used in the study. Linkage analyses and map construction of RGAP markers and the resistance loci were performed using the computer program Mapmaker, version 3.0 (20). A log of the likelihood ratio score of 3.0 and Kosambi's mapping function (19) were used to establish the linkage.

\section{RESULTS}

Phenotypic and genetic analyses. Both races PST-41 and PST45 produced IT 0 on Steptoe and IT 8 on Russell. All $F_{1}$ plants had IT 0 in tests with both races. Of $150 \mathrm{~F}_{2}$ plants from the Steptoe $\times$ Russell cross tested with race PST-45, 47 had IT 0, 73 had IT 1, 9 had IT 2, 3 had IT 7, and 18 had IT 8; none of the plants 
had IT 3, 4, 5, 6, or 9. Plants with IT 0, 1, and 2 were considered resistant because uredia were not produced and those with IT 7 and 8 were considered susceptible because abundant uredia were produced. The $F_{2}$ segregation fits a ratio of 13 resistant to 3 susceptible when inoculated with race PST-45, indicating one dominant and one recessive gene in Steptoe for resistance to PST45 (Table 1). The segregation of the backcross to Russell fits a 1:1 ratio for resistant and susceptible plants. All plants of the backcross to Steptoe were resistant (Table 1). $\mathrm{F}_{3}$ lines derived from the $F_{2}$ progeny segregated in a ratio of 7:8:1 resistant:segregating:susceptible when inoculated with either PST-41 or PST-45. Of the $\mathrm{F}_{3}$ lines derived from the $21 \mathrm{~F}_{2}$ plants that were susceptible when tested with PST-45, 13 segregated and 8 were homozygous susceptible when tested with both PST-41 and PST-45 (Table 1). These results confirm the presence of two genes acting epistatically for resistance in Steptoe, one dominant and one recessive gene for resistance to both races. Furthermore, there was no difference in reaction categories (homozygous resistant, segregating, and homozygous susceptible) for the $\mathrm{F}_{3}$ lines inoculated with the two $P$. striiformis f. sp. tritici races (Table 1). All eight $F_{3}$ lines that were susceptible to PST-45 also were susceptible to PST-41. Only one line that was resistant when tested with PST-45 was segregating when tested with PST-41, which might be due to the limited number of plants used in the tests. The $\chi^{2}$ test $(P=0.39)$ of reaction categories in a two-gene model for the $\mathrm{F}_{3}$ lines inoculated with races PST-41 and PST-45 (data not shown) indicate that the resistance for both races is controlled by the same genes. Reaction categories were analyzed in a three-gene model $(P<0.001)$ to check for the presence of a common gene conferring resistance to both PST-41 and PST-45 in association with two different genes conferring resistance to the individual races. Reaction categories also were analyzed in a four-gene model $(P<0.001)$ to conclusively reject the presence of four genes involved in resistance (data not shown). Furthermore, evidence for this conclusion was provided by the fact that there were no $\mathrm{F}_{3}$ lines with a resistant reaction to PST-41 that showed a susceptible reaction to PST-45. Similarly, there were no $\mathrm{F}_{3}$ lines with a susceptible reaction to PST-41 that showed a resistant reaction to PST-45.

RGAP markers associated with resistance to $P$. striiformis $f$. sp. tritici races. In all, 390 primer pairs from 48 RGA primers were screened in pairs in bulk segregant analysis. Eleven primer pairs that produced 12 repeatable polymorphic bands that were present in Steptoe but absent in Russell and differentiated the resistant bulk from the susceptible bulk either by presence or absence or obvious band intensity difference were selected for cosegregation analysis using the $150 \mathrm{~F}_{2}$ plants. All identified RGAP markers were dominant. The 11 primers that produced polymorphic bands linked to one of the resistance loci are shown in Table 2. The fragment sizes and primer pairs of the 12 RGAP markers are shown in Table 3 . The banding pattern of a set of $F_{2}$ progeny screened with RGA primer pair PtoFen-AS/CLRR-For is shown in Figure 1. The RGAP markers were linked to the resistance gene with a genetic distance ranging from 0.7 to 29.4 centimorgans (cM) (Fig. 2).

Mapping the dominant resistance gene on barley chromosomes. Tests using the 14 microsatellite markers representing

TABLE 1. Observed number and expected ratio and number of resistant (Res), segregating (Seg), and susceptible (Sus) plants or lines in parents and $\mathrm{F}_{1}$, $\mathrm{F}_{2}$, backcrosses $\left(\mathrm{BC}_{1}\right)$, and $\mathrm{F}_{3}$ progeny of the cross Steptoe $\times$ Russell inoculated with races PST-41 and PST-45 of Puccinia striiformis $\mathrm{f}$. sp. tritici and probabilities of $\chi^{2}$ tests for goodness of fit ${ }^{\mathrm{a}}$

\begin{tabular}{|c|c|c|c|c|c|c|c|c|c|c|}
\hline \multirow[b]{3}{*}{ Race, generation } & & & & \multicolumn{6}{|c|}{ Expected plants or lines } & \multirow[b]{3}{*}{$P$} \\
\hline & \multicolumn{3}{|c|}{ Observed no. plants or lines } & \multicolumn{3}{|c|}{ Ratio } & \multicolumn{3}{|c|}{ Number } & \\
\hline & Res & Seg & Sus & Res & Seg & Sus & Res & Seg & Sus & \\
\hline $\mathrm{P}_{1}$ (Steptoe) & 7 & $\ldots$ & 0 & 1 & $\ldots$ & 0 & 7 & $\ldots$ & 0 & $\ldots$ \\
\hline $\mathrm{P}_{2}$ (Russell) & 0 & $\ldots$ & 8 & 0 & $\ldots$ & 1 & 0 & $\ldots$ & 8 & $\ldots$ \\
\hline $\mathrm{F}_{1}$ & 5 & $\ldots$ & 0 & 1 & $\ldots$ & 0 & 5 & $\ldots$ & 0 & $\ldots$ \\
\hline $\mathrm{F}_{2}$ & 129 & $\ldots$ & 21 & 13 & $\ldots$ & 3 & 122 & $\ldots$ & 28 & 0.14 \\
\hline $\mathrm{F}_{3}$ & 75 & 67 & 8 & 7 & 8 & 1 & 66 & 75 & 9 & 0.33 \\
\hline \multicolumn{11}{|l|}{ PST-41 } \\
\hline $\mathrm{P}_{1}$ (Steptoe) & 8 & $\ldots$ & 0 & 1 & $\ldots$ & 0 & 8 & $\ldots$ & 0 & $\ldots$ \\
\hline $\mathrm{P}_{2}$ (Russell) & 0 & $\ldots$ & 10 & 0 & $\ldots$ & 1 & 0 & $\ldots$ & 10 & $\ldots$ \\
\hline $\mathrm{F}_{1}$ & 5 & $\ldots$ & 0 & 1 & $\ldots$ & 0 & 5 & $\ldots$ & 0 & $\ldots$ \\
\hline $\mathrm{BC}_{1}$ (to Steptoe) & 40 & $\ldots$ & 0 & 1 & $\ldots$ & 0 & 40 & $\ldots$ & 0 & $\ldots$ \\
\hline $\mathrm{BC}_{1}$ (to Russell) & 23 & $\ldots$ & 17 & 1 & $\ldots$ & 1 & 20 & & 20 & \\
\hline
\end{tabular}

a ... Indicates not applicable.

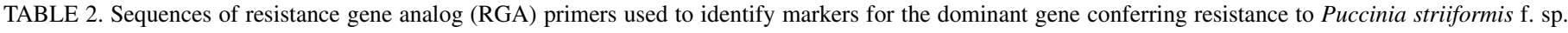
tritici in Steptoe barley

\begin{tabular}{|c|c|c|c|}
\hline RGA primer & Sequence $\left(5^{\prime}-3^{\prime}\right)$ & Gene & Domain $^{\mathrm{a}}$ \\
\hline Pto kin 1 & GCATTGGAACAAGGTGAA & Pto & Kinase \\
\hline Pto kin2 & AGGGGGACCACCACGTAG & Pto & Kinase \\
\hline Pto Fen-AS & TTGGCACAAAATTCTCATCAAGC & Pto & Kinase \\
\hline CLRR-For & TTTTCGTGTTCAACGACG & Cf9 & LRR \\
\hline RLRR-For & CGCAACCACTAGAGTAAC & $\operatorname{Rps} 2$ & LRR \\
\hline RLK-For & GAYGTNAARCCIGAR & LrK10 & Kinase \\
\hline NBS-F1 & GGAATGGGNGGNGTNGGNAARAC & $N, \operatorname{Rps} 2$ & NBS \\
\hline XLRR-INV1 & TTGTCAGGCCAGATACCC & $X a 21$ & LRR \\
\hline XLRR-INV2 & GAGGAAGGACAGGTTGCC & $X a 21$ & LRR \\
\hline LM637 & ARIGCTARIGGIARICC & L6, N, Rps 2 & P-loop \\
\hline AS3 & IAGIGCIAGIGGIAGICC & $N, \operatorname{Rps} 2$ & P-loop \\
\hline
\end{tabular}

a $\mathrm{LRR}=$ leucine-rich repeat. 
each arm of the seven barley chromosomes indicated that codominant marker HVM68 of $\approx 204$ bp (primer pair HVM68-F: 5'AGGACCGGATGTTCATAACG-3' and HVM68-R: 5'-CAAATCTTCCAGCGAGGCT- $3^{\prime}$ ), which is associated with barley chromosome $4 \mathrm{H}$ (23), was linked to the locus of the dominant resistance gene in Steptoe. The larger fragment $(\approx 204 \mathrm{bp})$ was linked in coupling to the resistance allele in Steptoe. The two-point linkage analysis using computer program Mapmaker (version 3.0) (20) indicated that HVM68 was linked to the resistance allele at a distance of $11.6 \mathrm{cM}$. The microsatellite marker also was integrated into the RGAP linkage group (Fig. 2). These results showed that the dominant resistance gene in Steptoe against $P$. striiformis f. sp. tritici was on chromosome $4 \mathrm{H}$.

\section{DISCUSSION}

Plant disease resistance generally has been categorized as nonhost and host resistance. However, there are plant-microbe interactions that do not fit clearly into either of the two categories. As shown in this study and previous studies $(6,21)$, barley cultivars occasionally are susceptible to the wheat stripe rust pathogen, $P$. striiformis f. sp. tritici. Similarly, wheat cultivars occasionally are susceptible to the barley stripe rust pathogen, $P$. striiformis f. sp. hordei $(6,29)$. In these studies, resistance in barley to $P$. striiformis f. $\mathrm{sp}$. hordei and resistance in wheat to $P$. striiformis f. sp. tritici are host resistance because a considerably high percentage of barley and wheat cultivars are susceptible to $P$. striiformis f. sp. hordei and P. striiformis f. sp. tritici, respectively. In contrast, barley never was damaged in the Pacific West of the United States before early 1990s, whereas devastating epidemics of stripe rust have occurred frequently since the later 1950s (21). P. striiformis f. sp. tritici and P. striiformis f. sp. hordei clearly were different in molecular relationship and have wheat and barley, respectively, as their most favorable hosts (6).

TABLE 3. Resistance gene analog polymorphism (RGAP) markers for the dominant gene conferring resistance to Puccinia striiformis f. sp. tritici in Steptoe barley, primers used to identify the marker, and the size of the markers

\begin{tabular}{llc}
\hline Marker $^{\mathrm{a}}$ & RGAP primer pair & Size $(\mathrm{bp})^{\mathrm{b}}$ \\
\hline M1 & PtoFen-AS/AS3 & 280 \\
M2 & PtoFen-AS/LM637 & 460 \\
M3 & Pto kin1/XLRR-INV1 & 300 \\
M4 & PtoFen-AS/Pto kin2 & 480 \\
M5 & PtoFen-AS/CLRR-For & 400 \\
M6 & PtoFen-AS/RLRR-For & 500 \\
M7 & PtoFen-AS/RLK-For & 440 \\
M8 & PtoFen-AS/Pto kin1 & 460 \\
M9 & PtoFen-AS/Pto kin1 & 340 \\
M10 & PtoFen-AS/Pto kin2 & 310 \\
M11 & Pto kin1/XLRR-INV2 & 320 \\
M12 & PtoFen-AS/NBS-F1 & 350 \\
\hline
\end{tabular}

a All markers were present in Steptoe and absent in Russell.

${ }^{\mathrm{b}}$ Sizes were estimated based on 1-kb ladder plus.
Because $P$. striiformis f. sp. tritici occasionally infects barley and $P$. striiformis f. sp. hordei occasionally infects wheat, resistance in barley to $P$. striiformis f. sp. tritici and resistance in wheat to $P$. striiformis f. sp. hordei should not be considered nonhost resistance. Instead, we may consider barley an unfavorable host to $P$. striiformis f. sp. tritici and wheat an unfavorable host to $P$. striiformis f. sp. hordei. Resistance in unfavorable hosts has been referred to as resistance to "inappropriate pathogen" $(16,25$, $28,33,41,42)$.

In contrast to studies on nonhost resistance in fungi, which lead to the conclusion that nonhost resistance is multi-component, genetically complex, and pathogen nonspecific (14), Niks (27) states that the potential to reveal new genes for resistance in hybrids of formae speciales of rust fungi provides evidence of gene-for-gene interactions in the control of nonhost resistance at least to formae

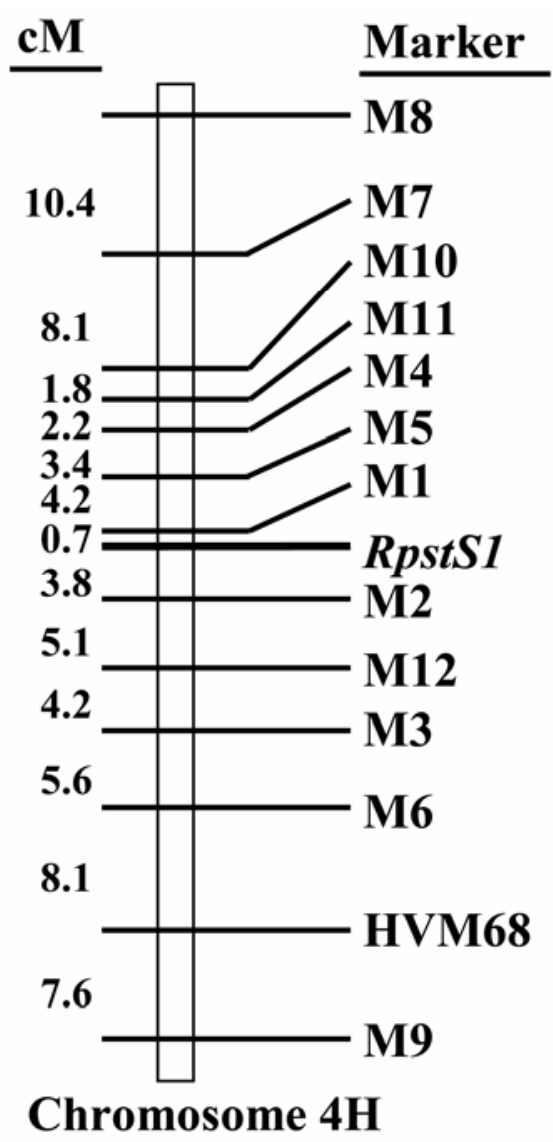

Fig. 2. Linkage map for a dominant gene (RpstSI) in cv. Steptoe for resistance to Puccinia striiformis f. sp. tritici constructed with 12 resistance gene analog polymorphism markers (M1 to M12) and a microsatellite marker (HVM68) using the Mapmaker program (version 3.0). The linkage on the long arm of chromosome $4 \mathrm{H}$ was determined by the specific HVM68.

\section{$\mathbf{P}_{1} \mathbf{P}_{2}$}

$\mathbf{F}_{2}$

$\begin{array}{llllllllllllllllllllllllllllllll}\text { PT: } & \mathbf{R} & \mathbf{S} & \mathbf{R} & \mathbf{R} & \mathbf{R} & \mathbf{S} & \mathbf{R} & \mathbf{R} & \mathbf{R} & \mathbf{R} & \mathbf{S} & \mathbf{R} & \mathbf{R} & \mathbf{S} & \mathbf{R} & \mathbf{R} & \mathbf{S} & \mathbf{R} & \mathbf{R} & \mathbf{R} & \mathbf{R} & \mathbf{R} & \mathbf{S} & \mathbf{R} & \mathbf{R} & \mathbf{R} & \mathbf{R} & \mathbf{R}\end{array}$

$\begin{array}{lllllllllllllllllllllllllllllllllll}\text { GT: } & \mathbf{R} & \mathbf{S} & \mathbf{R} & \mathbf{R} & \mathbf{R} & \mathbf{S} & \mathbf{H} & \mathbf{R} & \mathbf{H} & \mathbf{R} & \mathbf{S} & \mathbf{H} & \mathbf{H} & \mathbf{S} & \mathbf{H} & \mathbf{H} & \mathbf{S} & \mathbf{R} & \mathbf{R} & \mathbf{R} & \mathbf{H} & \mathbf{R} & \mathbf{S} & \mathbf{R} & \mathbf{R} & \mathbf{H} & \mathbf{H} & \mathbf{H}\end{array}$

Fig. 1. Silver-stained denaturing polyacrylamide gel showing the resistance gene analog polymorphism marker (M5) amplified with Pto Fen-AS (5'-TTGGCACAAAATTCTCATCAAGC-3') and CLRR-For (5'-TTTTCGTGTTCAACGACG-3') in analysis of $\mathrm{F}_{2}$ progeny. $\mathrm{P}_{1}=$ the resistant parent, Steptoe; $\mathrm{P}_{2}=$ the susceptible parent, Russell; $\mathrm{PT}=$ phenotype; $\mathrm{GT}=$ genotype determined by $\mathrm{F}_{3}$ lines derived from the $\mathrm{F}_{2}$ plants; $\mathrm{R}=$ resistant for PT and homozygous resistant for GT; $\mathrm{S}=$ susceptible for PT and homozygous susceptible; and $\mathrm{H}=$ heterozygous. 
speciales of rust fungi. Similar to several previous studies $(18,25,29,36,37)$, this study provided genetic evidence for a genefor-gene relationship between formae speciales of rusts and unfavorable host plants.

In previous studies on the interactions between barley and wheat stripe rust, $P$. striiformis f. sp. tritici, Chen et al. (6) revealed that races PST-3, PST-22, PST-41, and PST-45 of $P$. striiformis $\mathrm{f}$. sp. tritici are virulent on barley genotype Russell. In this study, Russell was susceptible to races PST-41 and PST-45, whereas Steptoe was resistant. Genetic analysis of the cross Steptoe $\times$ Russell indicated the presence of two genes in Steptoe, one dominant and one recessive, conferring resistance to both races. Co-segregating analyses of reactions to races PST-41 and PST-45 best support a model including the same two genes conferring resistance to both races. This is the first report of barley genes for resistance to the "inappropriate" forma specialis $P$. striiformis $\mathrm{f}$. sp. tritici. We provisionally designate the dominant resistance gene in Steptoe as RpstS1 and the recessive resistance gene rpstS2. Further studies are needed to determine whether other barley genotypes have genes similar to the ones identified in this study or have different genes for resistance to $P$. striiformis f. sp. tritici.

In this study, the bulk segregant analysis was used to screen potential markers linked to the resistance genes, which resulted in a limited number of markers for the dominant gene. Only 10 resistant and 10 susceptible $F_{2}$ plants were used to get the resistant and susceptible bulk, respectively. The small number of plants used in bulking might exclude the plants with only the recessive resistance allele. In separate studies for identifying markers for recessive genes in barley cultivars for resistance to $P$. striiformis f. sp. hordei, we have identified markers co-segregating with dominant alleles for susceptibility, but have been unsuccessful for finding markers tightly linked to the recessive alleles for resistance (G. P. Yan and X. M. Chen, unpublished data), which let us postulate that the recessive resistance alleles might be deletions at the loci for susceptibility. Nevertheless, more studies are needed to map the recessive gene. This could be achieved by (i) including DNA from more $F_{2}$ plants or $F_{3}$ lines in the bulks, (ii) constructing another resistant bulk with $F_{2}$ plants or $F_{3}$ lines with only the recessive resistance allele, and (iii) using only the two parents to identify polymorphic markers and using the whole population to identify linked markers.

The genetics of resistance in barley to $P$. striiformis f. sp. hor$d e i$ and the virulence of the pathogen have been studied extensively. In the United States, studies by Chen and Line $(3,5)$ have resulted in the identification of over 30 Rps genes for resistance to $P$. striiformis f. sp. hordei. They also reported that the barley$P$. striiformis f. sp. hordei pathosystem consists of a large number of recessive genes for resistance. Steptoe does not have a gene conferring resistance to $P$. striiformis $\mathrm{f}$. sp. hordei because it is susceptible to all races of $P$. striiformis $\mathrm{f}$. sp. hordei identified so far in the United States (4; X. M. Chen, unpublished data). The number of genes and inheritance mode of the resistance in Steptoe against $P$. striiformis $\mathrm{f}$. sp. tritici are similar to those in other barley genotypes resistant to the barley stripe rust pathogen, P. striiformis f. sp. hordei (5).

It has been suggested that fungal specialization developed gradually through co-evolution with gramineous plants, culminating in the establishment of formae speciales (15). P. striiformis $\mathrm{f}$. $\mathrm{sp}$. hordei and $P$. striiformis f. sp. tritici have co-existed in Europe for more than a century (12). The origin of the isolates of P. striiformis $\mathrm{f}$. sp. hordei in the United States is assumed to be in Europe, from which it spread via South America and Mexico $(1,11,32)$. Although the two formae speciales have been identified as clearly separate groups using isozyme and dsRNA analyses (26), as well as random amplified polymorphic DNA analyses (6), the possibility exists that races of the two formae speciales share many loci for pathogenicity. Furthermore, this study provides evidence that resistance in barley to $P$. striiformis f. sp. tritici is con- trolled by a few major genes. Therefore, it is possible to introgress the resistance into wheat for control of wheat stripe rust. This could be achieved through chromosomal manipulation or transformation. However, more studies are needed to develop techniques to introduce barley genes into wheat through chromosomal manipulation. The linkage group established in this study may serve as a starting point toward cloning the barley gene, which may be used to transform susceptible wheat cultivars for developing resistant ones. Even through we identified a marker only $0.7 \mathrm{cM}$ away from the dominant gene, closer markers are needed to clone the resistance gene.

One of the incentives to study resistance in nonhosts and unfavorable hosts is to utilize the types of resistance in favorable hosts because such resistance may be nonspecific and durable. Based on Johnson's (17) definition of durable resistance, resistance of Steptoe to $P$. striiformis f. sp. tritici could be considered durable because the cultivar has been widely grown in the Pacific West for more than 30 years and the region has had weather conditions for stripe rust epidemics on wheat in at least 3 of every 4 years. However, resistance controlled by a single gene from an alien species may not provide durable resistance when introgressed into a favorable host. The best example is the $\mathrm{Yr} 9$ resistance to $P$. striiformis $\mathrm{f}$. sp. tritici. The gene was originally from rye and introgressed into many wheat cultivars worldwide through chromosomal substitutions and translocations (40). Today, races or pathotypes of $P$. striiformis f. sp. tritici that circumvent the $\mathrm{Yr} 9$ resistance occur all over the world $(9,38)$. As shown in this study, the Steptoe resistance to $P$. striiformis $\mathrm{f}$. sp. tritici is controlled by two major genes, which may suggest that, like other single genes, these genes may not confer infinitely durable resistance by themselves. Nevertheless, these genes may provide effective resistance to $P$. striiformis f. sp. tritici when introduced into wheat cultivars.

\section{ACKNOWLEDGMENTS}

We thank R. F. Line, S. E. Ullrich, and anonymous reviewers for their valuable review and comments on the manuscript.

\section{LITERATURE CITED}

1. Chen, F. Q., Prehn, D., and Hayes, P. M. 1994. Mapping genes for resistance to barley stripe rust (Puccinia striiformis f. sp. hordei). Theor. Appl. Genet. 88:215-219.

2. Chen, X. M., and Line, R. F. 1992. Inheritance of stripe rust resistance in wheat cultivars used to differentiate races of Puccinia striiformis in North America. Phytopathology 82:633-637.

3. Chen, X. M., and Line, R. F. 1999. Recessive genes for resistance to Puccinia striiformis f. sp. hordei in barley. Phytopathology 89:226-232.

4. Chen, X. M., and Line, R. F. 2001. Races of barley stripe rust in the United States. Barley Newsl. 44.

5. Chen, X. M., and Line, R. F. 2003. Identification of genes for resistance to Puccinia striiformis f. sp. hordei in 18 barley genotypes. Euphytica 129:127-145.

6. Chen, X. M., Line, R. F., and Leung, H. 1995. Virulence and polymorphic DNA relationships of Puccinia strifformis f. sp. hordei to other rusts. Phytopathology 85:1335-1342.

7. Chen, X. M., Line, R. F., and Leung, H. 1998. Genome scanning for resistance-gene analogs in rice, barley, and wheat by high-resolution electrophoresis. Theor. Appl. Genet. 97:345-355.

8. Chen, X. M., and Moore, M. K. 2002. Epidemics and races of Puccinia striiformis in North America in 2001. (Abstr.) Phytopathology 92(suppl.): S14.

9. Chen, X. M., Moore, M. K., Milus, E. A., Long, D., Marshall, D., Line, R. F., and Jackson, J. 2002. Wheat stripe rust epidemics and races of Puccinia striiformis f. sp. tritici in the United States in 2000. Plant Dis. 86:39-46.

10. Chen, X. M., Moore, M. K., and Wood, D. A. 2003. Epidemics and control of stripe rust on spring wheat in the Pacific Northwest in 2002. (Abstr.) Phytopathology 93(suppl.):S16.

11. Dubin, H. J., and Stubbs, R. W. 1986. Epidemic spread of barley stripe rust in South America. Plant Dis. 70:141-144.

12. Eriksson, J. 1894. Uber die Spezialisierung des Parasitismus bei den Getreiderostpilzen. Ber. Dtsch. Bot. Ges. 12:292-331. 
13. Flor, H. H. 1971. Current status of the gene-for-gene concept. Annu. Rev. Phytopathol. 9:275-296.

14. Heath, M. C. 1981. A generalized concept of host-parasite specificity. Phytopathology 71:1121-1123.

15. Heath, M. C. 1991. The role of gene-for-gene interactions in the determination of host species specificity. Phytopathology 81:127-130.

16. Hoogkamp, T. J. H., Chen, W. Q., and Niks, R. E. 1998. Specificity of prehaustorial resistance to Puccinia hordei and to two inappropriate rust fungi in barley. Phytopathology 88:856-861.

17. Johnson, R. 1984. A critical analysis of durable resistance. Annu. Rev. Phytopathol. 22:309-330.

18. Johnson, R., and Lovell, N. K. 1994. Genetics of resistance of wheat to barley-attacking races of Puccinia striiformis. Cereal Rusts Powdery Mildews Bull. 22:32-40.

19. Kosambi, D. D. 1944. The estimation of map distances from recombination values. Ann. Eugen. 12:172-175.

20. Lander, E. S., Green, P., Abrahamson, J., Barlow, A., Daly, J. M., Lincoln, S. E., and Newberg, L. 1987. Mapmaker: An interactive computer package for constructing primary genetic linkage maps of experimental and natural populations. Genomics 1:174-181.

21. Line, R. F. 2002. Stripe rust of wheat and barley in North America: A retrospective historical review. Annu. Rev. Phytopathol. 40:75-118.

22. Line, R. F., Konzak, C. F., and Allan, R. E. 1974. Evaluating resistance to Puccinia striiformis in induced mutations for disease resistance in crop plants. Int. Atomic Energy Agency (IAEA) 180:125-132.

23. Liu, Z. W., Biyashev, R. M., and Maroof, S. M. A. 1996. Development of simple sequence repeat DNA markers and their integration into a barley linkage map. Theor. Appl. Genet. 93:869-876.

24. Maniatis, T. A., Frisch, E. F., and Sambrook, J. 1982. Molecular Cloning: A Laboratory Manual. Cold Spring Harbor Laboratory, Cold Spring Harbor, NY.

25. Matsumura, K., and Tosa, Y. 1995. The rye mildew fungus carries avirulence genes corresponding to wheat genes for resistance to races of the wheat mildew fungus. Phytopathology 85:753-756.

26. Newton, A. C., Johnson, R., and Caten, C. E. 1985. Isozyme and dsRNA analysis in isolates of three cereal rust species. Plant Pathol. 34:235-247.

27. Niks, R. E. 1988. Nonhost plant species as donors for resistance to pathogens with narrow host range. II. Concepts and evidence on the genetic basis of nonhost resistance. Euphytica 37:89-99.

28. Olesen, K. L., Carver, T. L. W., and Lyngkjaer, M. F. 2003. Fungal suppression of resistance against inappropriate Blumeria graminis formae speciales in barley, oat and wheat. Physiol. Mol. Plant Pathol. 62:37-50.

29. Pahalawatta, V., and Chen, X. M. 2005. Genetic analysis and molecular mapping of wheat genes conferring resistance to the wheat stripe rust and barley stripe rust pathogens. Phytopathology 95:427-432.

30. Rapilly, F. 1979. Yellow rust epidemiology. Annu. Rev. Phytopathol. 17:59-73.

31. Riede, C. R., and Anderson, J. A. 1996. Linkage of RFLP markers to an aluminum tolerance gene in wheat. Crop Sci. 36:905-909.

32. Roelfs, A. P., Huerta-Espino, J., and Marshall, D. 1992. Barley stripe rust in Texas. Plant Dis. 76:538.

33. Salmon, E. S. 1905. On the stages of development reached by certain forms of Erysophe in cases of noninfection. New Phytol. 4:217-222.

34. Shi, Z. X., Chen, X. M., Line, R. F., Leung, H., and Wellings, C. R. 2001. Development of resistance gene analog polymorphism markers for the Yr9 gene resistance to wheat stripe rust. Genome 44:509-516.

35. Stubbs, R. W. 1985. Stripe rust. Pages 61-101 in: The Cereal Rusts, Vol. II. A. P. Roelfs and W. R. Bushnell, eds. Academic Press, Orlando, FL.

36. Tosa, Y. 1989. Evidence on wheat for gene-for-gene relationship between formae specialis of Erysiphe graminis and genera of gramineous plants. Genome 32:918-924.

37. Tosa, Y., Tsujimoto, H., and Ogura, H. 1987. A gene involved in the resistance of wheat to wheatgrass powdery mildew fungus. Genome 29:850-852.

38. Wan, A. M., Zhao, Z. H., Chen, X. M., He, Z. H., Jin, S. L., Jia, Q. Z., Yao, G., Yang, J. X., Wang, B. T., Li, G. B., Bi, Y. Q., and Yuan, Z. Y. 2004. Wheat stripe rust epidemics and virulence of Puccinia striiformis $\mathrm{f}$. sp. tritici in China in 2002. Plant Dis. 88:896-904.

39. Yan, G. P., Chen, X. M., Line, R. F., and Wellings, C. R. 2003. Resistance gene-analog polymorphism markers co-segregating with the $\operatorname{Yr} 5$ gene for resistance to wheat stripe rust. Theor. Appl. Genet. 106:636-643.

40. Zeller, F. J. 1973. 1B/1R wheat-rye chromosome substitutions and translocations. Pages 209-221 in: Proc. 4th Int. Wheat Genet. Symp. E. R. Sears and L. M. S. Sears, eds. University of Missouri.

41. Zeyen, R. J., Kruger, W. M., Lyngkjær, M. F., and Carver, T. L. W. 2002. Differential effects of D-mannose and 2-deoxy-D-glucose on attempted powdery mildew fungal infection of inappropriate and appropriate Gramineae. Physiol. Mol. Plant Pathol. 61:315-323.

42. Zhang, H. S., De la Rosa, R., Rubiales, D., Lubbers, H. H., Molenveld, J. W., and Niks, R. E. 1994. Role of partial resistance to Puccinia hordei in barley in the defense of barley to inappropriate rust fungi. Physiol. Mol. Plant Pathol. 45:219-228. 